\title{
THE IMPACT OF AUDITORS' INDUSTRY KNOWLEDGE AND EXPERIENCE ON PREMATURE SIGN-OFFS: EVIDENCE FROM JORDAN
}

\author{
Khaled Isam AL-Qatamin \\ Faculty of Business, Economics and Social Development, Universiti Malaysia Terengganu \\ Zalailah Salleh* \\ Faculty of Business, Economics and Social Development, Universiti Malaysia Terengganu \\ Azwadi Ali \\ Faculty of Business, Economics and Social Development, Universiti Malaysia Terengganu
}

\begin{abstract}
This study aims to investigate the impact of auditors' industry knowledge (AIK) and auditor experience (EXP) on premature sign-offs (PMSOs) among external auditors. PMSOs is one of dysfunctional behaviours in auditing that eventually affects the audit quality. Audit quality is defined as all audit procedures are satisfactorily performed and stakeholders are not negatively affected with the results of poor audit quality. While the topic of audit quality has received great attention from previous studies decades ago, studies on how AIK and auditor experience affects PMSOs are limited. Therefore, this study examined the effects of AIK and auditor experience on PMSOs. Survey data was gathered from 144 auditors in the Jordanian audit firms. AMOS-SEM was used to analyse the data for testing the hypotheses. Results revealed that AIK and auditor experience negatively affected PMSOs. Based on these findings, this study suggests that to a certain extent PMSOs practices are prevalent in Jordanian audit firms, AIK, and auditor experience are a measure that can be used to reduce the PMSOs practices. Thus, this study provides empirical evidence of the impact factor determining the effect of auditor knowledge in the industry and auditor experience on the dysfunctional behaviour-PSMOs and impact on audit quality. The limitations of this study and recommendations for future research are also provided.
\end{abstract}

Keywords: Auditors' industry knowledge; Auditor experience; Audit quality; Premature sign-offs; External auditor, Jordan.

Received: 14 April 2020

Accepted: 27 September 2021

https://doi.org/10.33736/ijbs.4322.2021

\section{INTRODUCTION}

Specialization and experience play a vital role in making many fields effective and efficient including the audit field. Two of the factors affecting the audit quality are auditors' industry specialization and auditors experience year in auditing field. Auditors' industry specialization,

\footnotetext{
* Corresponding author: Faculty of Business, Economics and Social Development, Universiti Malaysia Terengganu, Kuala Terengganu, Malaysia; Email: zalailah@umt.edu.my
} 
which refers to industry- specific knowledge gathered from providing services to clients of the same industry (Gul et al., 2009; Al-Qatamin \& Salleh, 2020a). Auditors' industry specialization lets audit firms increase efficiency, make barriers to entry and improve audit quality (Solomon et al., 1999). Regulators and audit professionals have been wanting to regain the trust of the financial statements' users after the massive accounting and audit scandals, such as Enron and WorldCom. But following the collapse of Enron in 2001, and the consecutive turmoil of the auditing profession, audit quality has never improved (Moroney \& Carey, 2011). According to studies in the United Kingdom (UK), all top accountants have failed audit quality tests (Jones, 2019). For example, the Financial Reporting Council (FRC) found that the Big Four, as well as the second-tier firms BDO, Grant Thornton, and Mazars, all failed to reach the target of $90 \%$ of audits being satisfactory or requiring only minimal improvements (Jolly, 2019; Jones, 2019). In addition, among Britain's 350 top listed firms for the year ending December 2017, only $75 \%$ of the sample audits achieved the overall target of $90 \%$ because accountants failed to challenge the information they received from clients (Chapman, 2019; Jones, 2019). Similarly, in 2014 the Jordan Association of Certified Public Accountants (JACPA) had penalised a number of auditors, who were alleged for failing to comply with International Auditing Standards (ISA) and ethical rules by preventing them from providing auditing services for two years. Previously, in 2013, the JACPA penalised five auditors who were members of the association for non-compliance with ethical rules by prohibiting them from practising between six to 12 months. These issues demonstrate the poor quality of auditing in Jordan (Yazan Yaseen et al., 2019).

Abernathy et al. (2015) confirmed that personnel with high levels of job experience provide better auditing quality. In recent decades, most corporations have operated in the global market, resulting in concerns about whether they have the required experience to conduct quality audits that have not been prematurely signed off. Espinosa-Pike and Barrainkua (2016) suggested that auditors with less experience are more likely to manifest dysfunctional audit behaviour - PMSOs. In addition, previous research argued that PMSOs may occur when auditors fail to perform certain required audit procedures or intentionally leave out audit procedures but record them as completed (Shapeero et al., 2003; Hyatt \& Taylor, 2013). According to Graham (1985) audit failures typically happen because of the omission of audit procedures rather than those procedures being applied to an inadequate number of items. Thus, the auditor's behaviour during audit fieldwork determines the quality of audit (Yuen et al., 2013). While previous studies examine the effect of auditors' industry specialization or AIK on audit quality, most of the studies employed secondary data in which limits the ability to gauge the behaviour of auditors. Therefore, it is imperative to investigate factors affecting audit quality from auditors' behaviour perspective using primary data.

Previous research argued that PMSOs of audit procedures because of incompetence negatively affects the quality of auditing at the international level (Gunn \& Paul, 2018). In addition, Haislip et al. (2016) found that a lack of training and adequate knowledge affected the performance of auditors and the quality of auditing in information technology firms. Thus, for this reason, auditors may engage in dysfunctional audit behaviour such as PMSOs while neglecting audit procedures (Svanström, 2016). Additionally, auditors with little or no experience found it difficult to meet deadlines, and accepted clients' explanations with little factual information to support auditing. Blankley et al. (2015) found that PMSOs of superficial documents, together with weak client justifications, caused direct risks to the quality of the audit reports. Similarly, inexperienced auditors may view some procedures as irrelevant, thus, neglecting important steps that may affect 
auditing. Ideally, auditors should perform all audit procedures and provide a realistic assurance of clients' financial records (Olatunji \& Adekola, 2017).

Studies on the effects of dysfunctional audit behaviour have stemmed from the importance of explaining variations in audit quality. These include studies on the effects of auditors' industry knowledge and experience on audit quality in the Jordanian context. Country specific characteristics may affect audit quality due political and regulatory environment (Abdul Wahab et al., 2011). Jordan is a developing country with a small economy, and most Jordanian firms are small and family-owned. Therefore, a strategy is needed to maintain a high level of external audit quality that results in high quality financial statements. Research based on Jordanian firms may provide a variety of empirical evidence on audit quality from different jurisdictions. Thus, the results of this study may also offer insight and guidance to regulators and standard setters in JACPA to consider measures for improvements in the external audits from a behavioural perspective. In addition, the findings of this study will extend knowledge concerning the ways auditors in Jordan typically manage audit procedures and their industry knowledge to achieve high-quality audit thereby encouraging future research to be conducted on the value of audit quality. While previous studies examine the effects of auditors' industry knowledge and auditor experience on audit quality, limited studies conducted to investigate the relationship between auditors' industry knowledge, auditor experience and PMSOs. Thus, this study aims to investigate the impact of auditors' industry knowledge and auditor experience on premature sign-offs (PMSOs) among external auditors.

\section{LITERATURE REVIEW AND HYPOTHESES}

\subsection{Industry knowledge and PMSOs}

Specialization plays a vital role in making many fields effective and efficient including the audit field. One of the factors affecting the audit quality is auditors' industry specialization, which refers to industry- specific knowledge gathered from providing services to clients of the same industry (Gul et al., 2009). Auditors' industry specialization lets audit firms increase efficiency, make barriers to entry and improve audit quality (Solomon et al., 1999; AL-Qatamin \& Salleh, 2020b).

Accounting firms recognize the importance of auditors' industry expertise in providing highquality audits and they strategically organize their assurance practices along the industry lines. A report on the US audit market issued by the US Government Accountability Office (GAO) in 2008 also acknowledged the importance of auditors' industry expertise, noting that "auditors with industry expertise may exploit their specialization by developing and marketing audit related services specific to clients in the industry and provide a higher level of assurance" (GAO, 2008, p. 111). The importance of auditors' industry expertise has led auditing researchers to extensively study its impact on audit quality. Experimental auditing research provides evidence that auditors with industry expertise generally enhances their judgment. Specifically, the findings of prior studies suggest that the auditor's knowledge of the industry increases audit quality (Gaver \& Utke, 2019), improves the accuracy of error detection (Solomon et al., 1999; Owhoso et al., 2002), enhances the quality of the auditor's risk assessment (Taylor, 2000; Low, 2004), and influences the choice of audit tests and better allocation of audit hours (Low, 2004). Also, the emphasis on global professional auditing standards is growing to understand the client's industry and business. One example is the standards of audit quality control in the US (American Institute of Certified 
Public Accountants, 1993), which emphasizes the importance of identifying, designating and developing industry specialist auditors (Gramling \& Stone, 2001). The specialization of the audit field focuses on the accounting and auditing literature and the impacts on several proxies, such as audit quality. In addition, it creates barriers to entry for competitors. The importance of auditors' industry specialization in enhancing the performance of the auditor and audit quality can be found as the main direction in the literature. In recent years, many audit firms were brought towards the goal of reengineering their activities in the audit field based on the auditors' industry specialization to provide audit services that are more effective and assuring. To achieve multiple objectives, audit firms develop industry specialization, which helps to increase the demand for audit or non-audit services in the focal industry (Gramling \& Stone, 2001).

The auditors' industry specialization also significantly improves the efficiency of firms through economic scales resulting from concentrating resources and technology investments (Hogan \& Jeter, 1999). An audit firm has generally been regarded in prior research as an industry specialized firm if it audits more than $10 \%$ of firms or sales in an industry (DeFond, 1992; Craswell et al., 1995). The auditors' specialization of the audit industry implies extensive knowledge of the environment of the client's business and also the accounting practices, which are potentially illegitimate (Fernando et al., 2010). Casterella et al. (2004, p.124) stated that the specialization of the audit industry is "a differentiation strategy whose purpose is to provide auditors with a sustainable competitive advantage over non-specialists". An auditor's knowledge has a direct bearing on the quality of the audit. Knowledge, such as that accumulated through clients, tasks, and industry experience are examples of domain-specific knowledge, which are associated with a higher quality auditor (Bonner, 1990). Auditors with more domain-specific knowledge make more consistent decisions that comply with professional standards, and they are more likely to have a higher level of consensus (Bedard, 1989).

The level of client-specific knowledge has been found to be positively related to auditor performance over time (Beck \& Wu, 2006). Auditors with industry specialization have been found to outperform non- specialists in error detection (Owhoso et al., 2002) in performing analytical procedures (Wright \& Wright, 1997; Green, 2008), assessing components of audit risks (Taylor, 2000; Low, 2004; Hammersley, 2006; Moroney \& Simnett, 2009), and disclosing internal control deficiencies (Rose-Green et al., 2011; Stephens, 2011). Auditors' industry experience is empirically evident to be positively associated with compliance with the Generally Accepted Auditing Standards (O'Keefe et al., 1994). Therefore, an auditor with a higher level of industry experience would normally have lower abnormal accruals (Reichelt \& Wang, 2010) and reduced clients' cost of equity (Krishnan et al., 2013). Therefore, auditors ought to gain a clear understanding of the industry in the quest to build a profile and a risk assessment that will guide the audit procedures. In line with this realization, ISA 315 demands that auditors ought to gain insights into the company operations termed as a company and its environment (Kend, 2008; Wang et al., 2009). As Granberg and Höglund (2011) noted, the understanding will help the auditors in their risk assessments, and, subsequently, the quality of the audit.

Understanding the company is an important element of the audit as it allows auditors to identify areas that require immediate interventions (Knechel, 2007). The process of audit involves the review and reporting of information about the company's stewardship and compliance with the accounting requirements as set by the guiding accounting standards and industry regulations (Okoye \& Ofoegbu, 2006). Therefore, understanding the industry is an important milestone that 
will allow the auditors to assess if the company is in compliance with the set standards. The industry information allows the auditors to set expectations and investigate variances in the quest to boost the audit quality (Ettredge et al., 2008; Hakim \& Omri, 2010). It is argued that acceptance of a new client does not have a direct influence on the audit quality. This is supported by Havasi and Darabi (2016) who reported that the auditor's specialty has no significant impact on the financial reporting quality of the statistical sample. However, Liu et al. (2017) pointed out that there are risks associated when new auditors attempt to audit a new client. This relates to the possibility that the auditor's lack of knowledge of the client's industry may result in certain behavioural issues such as premature sign-off, reducing the amount of work performed on the audit step (Mohd Nor, 2011; Kelley \& Margheim, 1990; Otley \& Pierce, 1996), failing to research an accounting principle or technical issue (Mohd Nor, 2011; Otley \& Pierce, 1996; Kelley \& Margheim, 1990), making superficial reviews of client documents (Mohd Nor, 2011; Malone \& Roberts, 1996; Otley \& Pierce, 1996; Kelley \& Margheim, 1990), and accepting weak client explanations (Mohd Nor, 2011; Paino, Smith \& Ismail, 2010; Gundry \& Liyanarachchi, 2007; Coram et al., 2003; Malone \& Roberts, 1996; Otley \& Pierce, 1996; Kelley \& Margheim, 1990).

Past research shows that auditors have deliberately signed-off various audit procedures. For example, Alderman and Deitrick (1982) carried out a primary research to investigate the presence and tendency of auditors to accept and apply the concept of premature sign-off. The subsequent results revealed that 31 percent of the respondents agreed that they frequently observed the occurrence of premature sign-off, thereby highlighting the scale of premature sign-off and its acceptability in the audit world. As a result, it would not be incorrect to express that premature sign-offs have really affected audit quality (Al-Qatamin, 2020; Agoglia et al., 2015). Within this context, it is vital to acknowledge that when an auditor fails to take a professional approach and interest in carrying out an audit procedure (Barrainkua \& Espinosa-Pike, 2015), this lack of interest results in premature sign-off, and, subsequently, affects the audit quality (Herrbach, 2001). There could be various reasons behind this lack of interest; for example, if an auditor is new and has no related or prior experience of audit and has been asked to perform complex and lengthy audit procedures. Such a situation would certainly discourage the auditor from performing all the necessary steps which is essential for completing this type of audit procedure to satisfy the audit objectives (Pierce \& Sweeney, 2004). Precisely, the audit firm has a responsibility to detect that an audit has been poorly done by an auditor. Thus, the audit manager is accountable for establishing and supervising to ensure that the audit completion complies with the audit plan (Sarens \& Abdolmohammadi, 2011). In addition, they are expected to manage the auditors to ensure the audit steps are finalized following all the appropriate requirements. Regarding this, the managers are responsible for these dysfunctional behaviours if they do not undertake the required supervision.

It is argued that acceptance of a new client does not have a direct influence on the audit quality. This is supported by Havasi and Darabi (2016) who reported that the auditor's specialty has no significant impact on the financial reporting quality of the statistical sample. However, Liu et al. (2017) pointed out that there are risks associated when new auditors attempt to audit a new client. This highlights that the auditors who have less experience in a particular industry are likely to manifest dysfunctional behaviour, such as the tendency to resort to premature sign-off on an audit step.

H1: There is a significant relationship between auditors' industry knowledge and premature sign-offs. 


\subsection{Auditor experience and PMSOs}

Auditor experience is an important input element and has a direct effect on audit quality (Mednick, 1990; Bonner, 1990). Accounting firms recognize the importance of auditor experience in providing high- quality audits and they strategically organize their assurance practices along the industry lines (Gul et al., 2009). Before joining an audit firm, a prospective auditor is required to pass various technical examinations and other tests essential to test and improve the audit-related technical competency and professional level. For example, Certified Public Auditor, and other related local and international certifications are additional examples highlighting the importance of audit experience and qualifications for auditor. At the same time, if an auditor has qualified via a professional auditing course in a timely manner and has also received certification, this would enable the auditor to become a part of an audit firm and provide their audit services to their clients. Additionally, according to Fredrick and Libby (1986), Bedard (1989), Bonner and Lewis (1990), Beck and Wu (2006), and Owhoso et al. (2002) auditors experience has been found to be positively related to audit quality. Auditors with experience year in auditing have the ability to detect and assess the risk and make decisions that are more consistent with professional standards (Taylor 2000; Low, 2004; Hammersley, 2006; Moroney \& Simnett 2009; Wright \& Wright 1997; Green, 2008). Auditor experience is a valuable input element, which is essential for improving audit quality (Saha \& Roy, 2017). After obtaining an audit-related qualification, an auditor is required to conduct various audit engagements in which they apply all of their theoretical and conceptual frameworks for understanding and evaluating the performance of the internal controls and other risk-related transactions and activities. However, in the beginning, it is rarely possible to apply and detect material misstatement because the auditor requires the support of experience to improve their audit-related estimations and judgments.

Additionally, the client's workplace environment, and their compliance with the local and international laws and regulations are some of the additional factors that are highly essential for the new auditor to understand properly before going to apply audit tests and audit procedures (Suyono, 2012). As a result, after a few years, the auditor improves their audit performance as the audit experience has considerably improved and encouraged the auditor to understand how clients use their accounting and other managerial activities to comply with local and international regulations. Despite that, auditors with less experience are more likely to engage in premature signoffs. According to Donnelly et al. (2003) found that auditor experience level to be negatively associated with dysfunctional audit behaviour. In addition, previous studies found that auditors who gain more experience years they are more likely to recognize the negative effects of dysfunctional audit behaviour (Alderman \& Deitrick, 1982; Kelley \& Seiler, 1982; Cook \& Kelley, 1988; Raghunathan, 1991; Shapeero et al., 2003; Donnelly et al., 2003). Lower level of auditors' experience is more likely to resort to dysfunctional audit behaviour - premature sign-offs and less concerned with the overall audit process as compared to those with a high level of experience years in the auditing filed.

H2: There is a significant relationship between auditors' experience and premature sign-offs. 


\section{METHOD}

\subsection{Sample and Data Collection}

This study employed survey method to collect the data. A total of 196 questionnaire was sent to selected Jordanian external auditors, who worked in either Big-Four or non-Big Four firms in Jordan. The target respondents for this study are auditors with a senior position and above, who have many years of experience in auditing. A period of 1 month was given to the respondents to answer the survey. A total of 144 respondents answered and completed the surveyed. Therefore, a response rate for the completed surveyed is $73.46 \%$.

\subsection{Instrumentation}

Instrumentation for Auditors' Industry Knowledge (AIK) was based on six survey items from Elshawarby (2017) and was adapted as an independent variable in this study. Auditors' industry specialization refers to industry-specific knowledge gathered from providing services to clients in the same industry (Gul et al., 2009). The respondents were asked to indicate the agreement level of each statement. Additionally, each statement was scored based on the Likert scale, which was arranged from one to five ("1" represents "Strongly disagree" and "5" represents "Strongly agree"). Instrumentation for Premature Sign-Offs (PMSOs) was based on nine items that measure PMSOs direct proxy of audit quality by Ling and Akers (2010). The measurements for audit quality can be similar to those used in studies conducted in other countries, due to widespread multinationals firms and the used of International Financial Accounting Standards in international businesses. The respondents were asked to indicate the agreement of premature sign-offs statement based on Likert scale, ranging from one to five (" 1 " represents "Strongly disagree" and "5" represents "Strongly agree"). Auditor experience (EXP) is measured in years as an auditor.

\section{RESULTS AND DISCUSSION}

\subsection{Sample Profile}

Among the respondents, $95.1 \%$ were males while a low percentage of respondents were females (4.9\%). The low percentage of female respondents due to Jordanian society does not encourage women to work as an auditor. In addition, the average respondents' age between 27 to 39, was $59.03 \%, 40$ to 55 was $29.86 \%$ and 56 and above, was $11.11 \%$. Hence, mostly respondents' age for this study were between 27 to 39 . The demographic analysis shows that most of the study respondents were audit senior with 47 out of 144 , which presented $32.6 \%$ of the study participants; while audit assistant manager were $27.1 \%$. Concerning education backgrounds, $88.2 \%$ of participants held BA degrees, $10.4 \%$ held a master's degree above, and $1.4 \%$ of participants held Ph.D.

\subsection{Exploratory factor analysis and Reliability test}

The Kaiser-Meyer-Oklin (KMO) and Bartlett's Test is used to test suitability of data for factor analysis. KMO value was 0.921 exceeding the recommended value of 0.70 which can be considered as adequate (Kaiser \& Rice, 1974) while Bartlett's Test of sphericity reached statistical 
significance (Approx. chi- square 1206.678, df 105 and Sig 0.000) which signifies the data is good for conducting factor analysis. The 15 items were subjected to Principal Component Analysis (PCA) with Varimax Rotation Method Kaiser Normalization is used for factor analysis. The items having factor loading less than 0.50 should be eliminated (Hair et al., 2010), but all factor loading for each item are above 0.50 suggesting that the data set is appropriate (Stewart, 1981). So, all 15 items are accepted and PCA revealed that these 15 items are grouped into 2 components with Eigen values exceeding 1 . The total percentage of variance is 61.008 . The individual dimensions of the proposed instrument explained total variance exceeding 61 percent, suggesting the appropriateness of the process. Table 1 below summarizes the results of the Principal Component Analysis.

Table 1: Factors Extraction Test

\begin{tabular}{ccc}
\hline \hline Item & Component Loading & Eigen Value \\
\hline AIK1 & 0.721 & 7.377 \\
AIK2 & 0.819 & \\
AIK3 & 0.749 & \\
AIK4 & 0.841 & \\
AIK5 & 0.745 & \\
AIK6 & 0.684 & \\
PMSO1 & 0.768 & \\
PMSO2 & 0.716 & \\
PMSO3 & 0.759 & \\
PMSO4 & 0.594 & \\
PMSO5 & 0.702 & \\
PMSO6 & 0.665 & \\
PMSO7 & 0.676 & \\
PMSO8 & 0.823 & \\
PMSO9 & 0.724 & \\
Total Variance Explained: & 61.008 & \\
\hline \hline
\end{tabular}

Reliability refers to the level of consistency among the variables over multiple measurements (Milne \& Adler, 1999; Hair et al., 2010). According to Kemani et al. (2019), the most commonly used instrument and scale for assessing a survey is internal consistency. Particularly, Cronbach's Alpha is frequently used in social sciences (Faran \& Zanbar, 2019). Hence, it was used in this study for independent variable namely auditor industry knowledge and the dependent variable audit quality, measured by auditor dysfunctional behaviour - PMSOs. The reliability value, Cronbach's Alpha, indicates that a high alpha value shows good internal consistency (Kraaij \& Garnefski, 2019; Gliem \& Gliem, 2003). The Cronbach's alpha for auditor industry knowledge were 0.889 and premature sign-offs were 0.907. In addition, the total Cronbach's alpha coefficient were 0.925, which represents a high level of internal consistency and reliability. As shown in the below Table 2:

Table 2: Reliability Test

\begin{tabular}{lcc}
\hline \multicolumn{1}{c}{ Items } & Cronbach's Alpha & No of Items \\
\hline AIK1, AIK2, AIK3, AIK4, AIK5, AIK6 & 0.889 & 6 \\
\hline PMSO1, PMSO2, PMSO3, PMSO4, PMSO5, & 0.907 & 9 \\
PMSO6, PMSO7, PMSO8, PMSO9 & & \\
\hline \hline
\end{tabular}




\subsection{Confirmatory Factor Analysis (CFA)}

Confirmation Factor Analysis explains the extent the observed variables are linked to the latent factors in the research. CFA postulates the relations between the variables based on the theory, empirical research or both and then test the hypothesized structure statistically. In this study the model is developed based on priori subject and CFA is used to confirm it. The measurement model represents the pattern in which each measure loads on a particular factor. It represents how the measured variables come together to represent construct and is used for validation and reliability checks. As shown in Figure 1 Confirmatory Factor Analysis.

Figure 1: Confirmatory Factor Analysis (CFA)

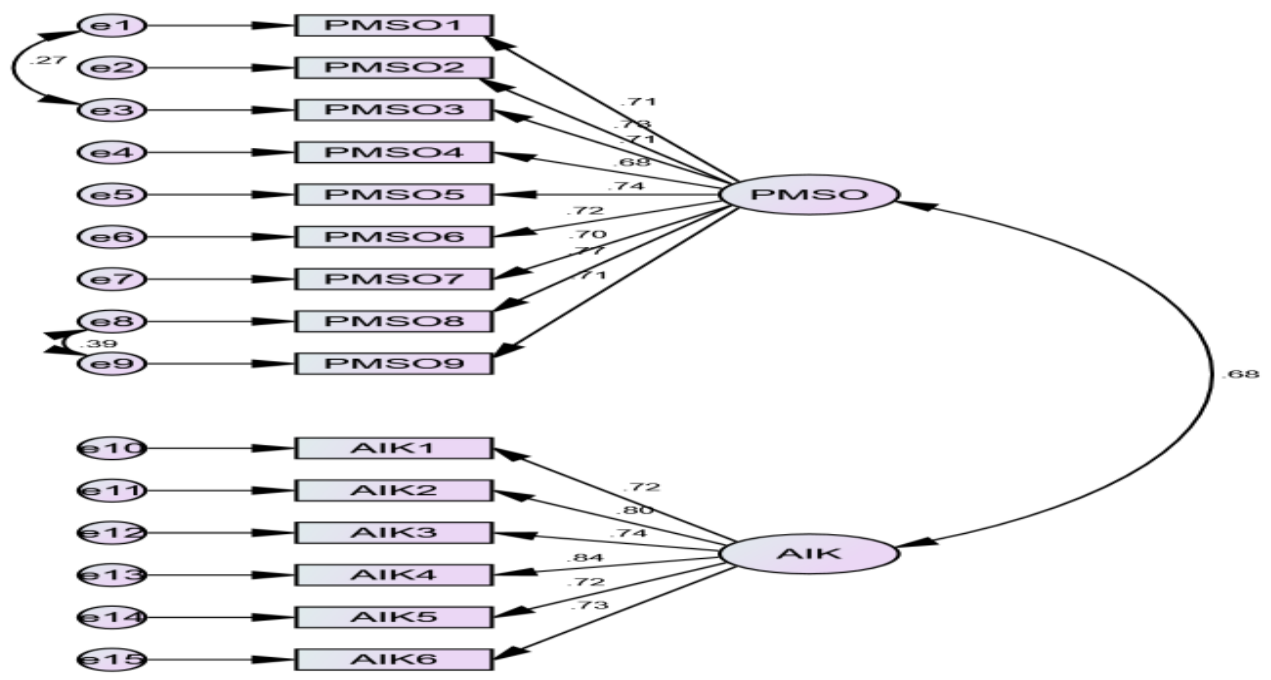

The measurement model represents the pattern in which each measure loads on a particular factor. It represents how the measured variables come together to represent construct and is used for validation and reliability checks.

Table 3: Covariance and Correlation between the latent variables

\begin{tabular}{|c|c|c|c|c|c|c|}
\hline \multicolumn{7}{|c|}{ Covariance between the Latent variables } \\
\hline & & & Estimate & S.E. & C.R. & $\mathrm{P}$ \\
\hline PMSO & $\langle--\rangle$ & AIK & 0.216 & 0.043 & 5.053 & $* * *$ \\
\hline e1 & $<-->$ & e3 & 0.076 & 0.028 & 2.722 & 0.006 \\
\hline e8 & $<-->$ & e9 & 0.082 & 0.023 & 3.595 & $* * *$ \\
\hline \multicolumn{7}{|c|}{ Correlation between the latent variables } \\
\hline \multicolumn{7}{|c|}{ Estimate } \\
\hline PMSO & $\langle-->$ & AIK & & & & \\
\hline e1 & $<-->$ & e3 & & & & \\
\hline $\mathrm{e} 8$ & $\langle->$ & e9 & & & & \\
\hline
\end{tabular}


There is a positive correlation of 0.678 between AIK and PMSO. The correlations between the other variables are given in the Table 3.

Based on Structure Equation Model using SPSS Amos 22 it is found that Chi-square $(\mathrm{CMIN})=$ 110.981, Degree of freedom $(\mathrm{DF})=87$ and probability level is about 0.042 . CMIN/DF is called as the minimum discrepancy which is 1.276 . Wheaton et al. (1977) suggested that if the minimum discrepancy is less than 5 the model is reasonable fit.

The following value are found in this study for each parameter to test model fit.

Table 4: Parameter value for model fit measures with SPSS Amos

\begin{tabular}{ll}
\hline \hline Name of the Parameter & Value \\
\hline Goodness of Fit Index (GFI) & 0.911 \\
Comparative Fit Index (CFI) & 0.979 \\
Root Mean Square Error of Approximation (RMSEA) & 0.044 \\
\hline \hline
\end{tabular}

Based on various studies conducted by Bentler and Bonett (1980), Bollen's (1989) and Bentler (1980), it was suggested that if the Index value is greater than 0.9 and if RMSEA values is less than 0.08 , it indicates model is fit and accepted.

\subsection{Reliability and validity tests}

Table 5 shows that all the variables are having Composite Reliability greater than 0.7 which indicate there is a good Composite Reliability in the variables. In addition, all the variables are having Convergent Validity greater than 0.5 which indicate there is good Convergent validity in the variables. The Discriminant value is greater than the corresponding correlation between the variables which indicate there is a good Discrimination between the factors in the analysis.

Table 5: Composite reliability, Convergent and Discriminant Validity

\begin{tabular}{lcc}
\hline \hline & CR & AVE \\
\hline PMSO & 0.906 & 0.517 \\
AIK & 0.892 & 0.579 \\
\hline \multicolumn{3}{c}{ Discriminant Validity } \\
\hline PMSO & PMSO & AIK \\
AIK & 0.719 & 0.761 \\
\hline \hline
\end{tabular}

\subsection{Structure Equation Model}

This study utilized Path Analysis in Structural Equation Modeling (SEM-AMOS) with 144 external auditor participants. As shown in Figure 2 The Standardized Regression Path Coefficient result. 
Figure 2: The Regression Path Coefficient between AIK and EXP on PMSO

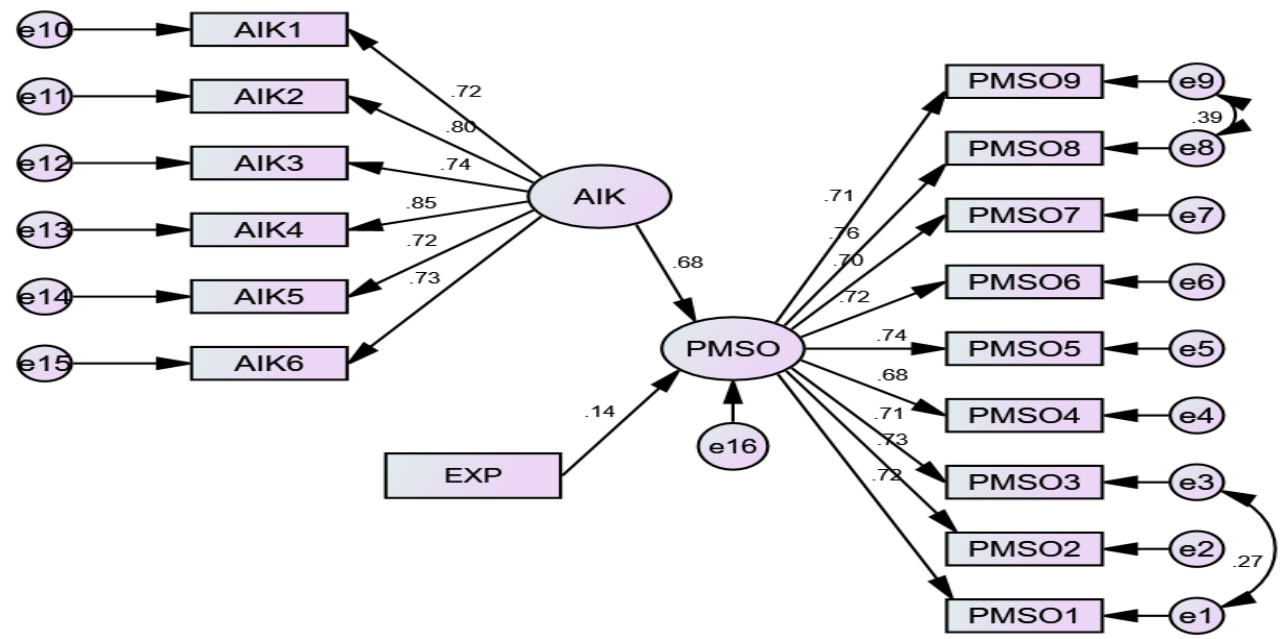

SPSS Amos Graphics has specified path-diagram specifies the relationship between the observed variables. The portion of the model that specifies how the variables are related to each other is called structural model. The estimates with the largest value represent the most important dimension in terms of its influence on dependent variables. The findings of the regression weights estimates are summarized in the Table 6 .

Table 6: The Regression Coefficient and its Significance

\begin{tabular}{lllrrrr}
\hline \hline & & & Estimate & S.E. & C.R. & P \\
\hline PMSO & $<---$ & AIK & 0.566 & 0.089 & 6.336 & $* * *$ \\
PMSO & $<--$ & EXP & 0.066 & 0.032 & 2.066 & 0.039 \\
PMSO3 & $<---$ & PMSO & 1.061 & 0.112 & 9.471 & $* * *$ \\
PMSO4 & $<---$ & PMSO & 0.912 & 0.118 & 7.730 & $* * *$ \\
PMSO5 & $<---$ & PMSO & 1.260 & 0.151 & 8.360 & $* * *$ \\
PMSO6 & $<---$ & PMSO & 1.144 & 0.140 & 8.194 & $* * *$ \\
PMSO7 & $<---$ & PMSO & 1.018 & 0.129 & 7.917 & $* * *$ \\
AIK1 & $<--$ & AIK & 1.000 & & & \\
AIK2 & $<--$ & AIK & 1.020 & 0.112 & 9.104 & $* * *$ \\
AIK3 & $<--$ & AIK & 0.941 & 0.111 & 8.489 & $* * *$ \\
AIK4 & $<---$ & AIK & 1.089 & 0.113 & 9.654 & $* * *$ \\
AIK5 & $<--$ & AIK & 0.936 & 0.113 & 8.292 & $* * *$ \\
AIK6 & $<--$ & AIK & 0.917 & 0.110 & 8.339 & $* * *$ \\
PMSO1 & $<--$ & PMSO & 1.000 & & & \\
PMSO2 & $<--$ & PMSO & 1.067 & 0.129 & 8.264 & $* * *$ \\
PMSO9 & $<--$ & PMSO & 0.944 & 0.118 & 7.988 & $* * *$ \\
PMSO8 & $<--$ & PMSO & 0.997 & 0.115 & 8.638 & $* * *$ \\
\hline \hline
\end{tabular}


Based on the result in Table 6, the study concludes the following:

i. $\quad$ Estimate: $\mathbf{0 . 5 6 6}$ - when the AIK increases by 1-unit, PMSOs increases by 0.566 .

$\mathbf{0 . 0 6 6}$ - when the EXP increases by 1-unit, PMSOs increases by 0.066 .

ii. C.R.: 6.336 - Dividing the regression weight estimate by the estimate of its standard error gives $z=0.566 / 0.089=6.336$. In other words, the regression weight estimate is 6.336 standard errors above zero.

2.066 - Dividing the regression weight estimate by the estimate of its standard error gives $\mathrm{z}=0.066 / 0.032=2.066$. In other words, the regression weight estimate is 2.066 standard errors above zero.

iii. $\mathbf{P}$-value shows the significance of the estimation. If the P-value is less than 0.05 then, there is a significant effect of the independent variable on dependent variable (P-Values with $* * *$ indicate 0.000$)$. All the Impacts are significant.

Thus, using the above findings (i, ii, and iii), the study infers that the hypotheses are supported.

Table 7: Standardized Regression weights Estimations

\begin{tabular}{lllc}
\hline \hline & & & Estimate \\
\hline PMSO & $<---$ & AIK & 0.678 \\
PMSO & $<---$ & EXP & 0.145 \\
PMSO3 & $<---$ & PMSO & 0.710 \\
PMSO4 & $<---$ & PMSO & 0.682 \\
PMSO5 & $<---$ & PMSO & 0.738 \\
PMSO6 & $<---$ & PMSO & 0.723 \\
PMSO7 & $<---$ & PMSO & 0.698 \\
AIK1 & $<---~$ & AIK & 0.721 \\
AIK2 & $<---$ & AIK & 0.796 \\
AIK3 & $<---$ & AIK & 0.742 \\
AIK4 & $<---$ & AIK & 0.846 \\
AIK5 & $<---$ & AIK & 0.725 \\
AIK6 & $<---$ & AIK & 0.729 \\
PMSO1 & $<---$ & PMSO & 0.716 \\
PMSO2 & $<---$ & PMSO & 0.730 \\
PMSO9 & $<---$ & PMSO & 0.708 \\
PMSO8 & $<---$ & PMSO & 0.765 \\
\hline \hline
\end{tabular}

i. The Auditors' Industry Knowledge has a significant impact of 0.678 on Premature Signoffs.

ii. The Experience has a significant impact of 0.145 on Premature Sign-offs.

iii. The Auditors' Industry Knowledge is impacting more than Experience on Premature Sign-offs.

Industry knowledge, skills and training associated with the nature of the client's business allow the auditor to conduct the audit in a more efficient and effective manner. The auditor who has spent more years in auditing a client in a specific industry is likely to have gained the needed expertise to conduct the audit. Moreover, an auditor who spent years to specialize in a specific industry is likely to complete a more efficient audit, compared to auditors who are new to the industry of the 
audit client. This suggests that familiarity with the client's industry is an important factor that allows the auditor to perform the audit in a more efficient manner. However, a rather low level of understanding of the client's business is likely to motivate the auditor to engage in dysfunctional behaviour such as premature sign- offs.

Based on Structure Equation Model using SPSS Amos 22 it is found that Chi-square $(\mathrm{CMIN})=$ 119.590, Degree of freedom $(\mathrm{DF})=101$ and probability level is about .100. CMIN/DF is called as the minimum discrepancy which is 1.184. Wheaton et al. (1977) suggested that if the minimum discrepancy is less than 5 the model is reasonable fit. The following value are found in this study for each parameter to test model fit.

Table 7: Parameter value for model fit measures with SPSS Amos

\begin{tabular}{ll}
\hline \hline Name of the Parameter & Value \\
\hline Goodness of Fit Index (GFI) & 0.910 \\
Comparative Fit Index (CFI) & 0.984 \\
Root Mean Square Error of Approximation (RMSEA) & 0.036 \\
\hline \hline
\end{tabular}

Based on various studies conducted by Bentler and Bonett (1980), Bollen's (1989) and Bentler (1980) as shown in Table 7, it was suggested that if the Index value is greater than 0.9 and if RMSEA values is less than 0.08 it indicates model is fit and accepted.

\section{CONCLUSION}

The main objective of this study was to examine the effect of AIK and auditor experience on premature sign-offs. There were negative relationships between AIK and auditor experience on PMSO. Accordingly, a high level of AIK reduced PMSO resulting increase in audit quality. Auditors with high knowledge in the client industries are more likely to have direct influence on the audit quality. In addition, it is argued that acceptance of a new client does not have a direct influence on the audit quality. This is supported by Havasi and Darabi (2016) who reported that the auditor's specialty has no significant impact on the financial reporting quality of the statistical sample, which contrary to the results of this study. The result of the current study was supported by the study of Liu et al. (2017). They pointed out that there are risks associated when auditors attempt to audit a new client. Therefore, auditors should have more experience and knowledge in the client industries. Moreover, this study showed that the high level of auditor industry knowledge and auditor experience leads to decrease the probability of auditors to engage in premature sign-offs, therefore, it leads to increase in the quality of audit performed by them. A finding of a high level of PMSO practices among Jordanian auditors resulting in few training opportunities for auditor in a specific industry. In addition, this is the first study conducted in Jordan that links AIK and auditor experience to PMSO. Furthermore, this study used primary data to examine the effect of AIK and auditor experience on audit quality. Most of previous studies used secondary data to investigate the relationship between the AIK, auditor experience and audit quality. Thus, this study extends previous literature by using primary data and SEM-AMOS analysis. Additionally, this study uses senior audits and above as a sample where they have extensive experience in auditing and thus provide a better overview of PMSO practices. This study is one of a few studies carried out focusing on auditors' dysfunctional behaviour in developing 
countries, particularly in the MENA countries such as Jordan. This is important as most studies related to AIK, EXP and audit quality have been conducted in developed countries such as the UK, USA, Norway, and Spain or in other developing countries such as Malaysia, Nigeria, Pakistan, Indonesia, and Iran.

\section{LIMITATION AND FUTURE DIRECTION}

In this study, only two variables (AIK and auditor experience) were considered. Future studies may include other independent variables such as time pressure and job satisfaction; or mediating variables such as job stress as the variable may reduce audit quality.

\section{REFERENCES}

Abdul Wahab, E. A., Mat Zain, M., \& James, K. (2011). Political connections, corporate governance and audit fees in Malaysia. Managerial Auditing Journal, 26(5), 393-418.

Abernathy, J. L., Beyer, B., Masli, A., \& Stefaniak, C. M. (2015). How the source of audit committee accounting expertise influences financial reporting timeliness. Current Issues in Auditing, 9(1), 1-9.

Agoglia, C. P., Hatfield, R. C., \& Lambert, T. A. (2015). Audit team time reporting: An agency theory perspective. Accounting, Organizations and Society, 44, 1-14.

Alderman, C. W., \& Deitrick, J. W. (1982). Auditors' perceptions of time budget pressures and premature sign-offs: A replication and extension. Auditing: A Journal of Practice \& Theory, 1(2), 54-68.

AL-Qatamin, K. I. (2020). The impact of time pressure on the audit quality: A case study in Jordan. IOSR Journal of Business and Management (IOSR-JBM), 22(1), 8-16.

AL-Qatamin, K. I., \& Salleh, Z. (2020a). Audit quality: A Literature overview and research synthesis. IOSR Journal of Business and Management (IOSR-JBM), 22(2), 56-66.

AL-Qatamin, K. I., \& Salleh, Z. (2020b). Overview of the audit profession in Jordan: Review the change and development of the profession. International Journal of Business Marketing and Management, 5(2), 33-38.

American Institute of Certified Public Accountants. Private Companies Practice Section. (1993). The Expectation gap standards: Progress, implementation issues, research opportunities. American Institute of Certified Public Accountants.

Barrainkua, I., \& Espinosa-Pike, M. (2015). New insights into underreporting of time: The audit partner context. Accounting, Auditing \& Accountability Journal, 28(4), 494- 514.

Beck, P., \& Wu, M. (2006). Learning by doing and audit quality. Contemporary Accounting Research, 23(1), 1- 30.

Bedard, J. (1989). Expertise in auditing: Myth or reality. Accounting, Organizations and Society, 14(1/2), 113-132.

Bentler, P. M. (1980). Multivariate analysis with latent variables: Causal modelling. Annual Review of Psychology, 31(1), 419-456.

Bentler, P. M., \& Bonett, D. G. (1980). Significance tests and goodness of fit in the analysis of covariance structures. Psychological Bulletin, 88(3), 588.

Blankley, A. I., Hurtt D. I., \& MacGregor J. E. (2015). Are lengthy audit report lags a warning signal? American Accounting Association, 9(2), 19-28. 
Bollen, K. A. (1989). Structural Equations with Latent Variables. John Wiley and Sons, Inc., New York.

Bonner, S. E. (1990). Experience effects in auditing: The role of task-specific knowledge. The Accounting Review, 65(1), 72-92.

Bonner, S. E., \& Lewis. B. L. (1990). Determinants of auditor expertise. Journal of Accounting Research, 28(Supplement), 1-19.

Casterella, J. R., Francis, J. R., Lewis, B. L., \& Walker, P. L. (2004). Auditor industry specialization, client bargaining power, and audit pricing. Auditing: A Journal of Practice \& Theory, 23(1), 123-140.

Chapman, B. (2019, July 10). PwC, KPMG, Deloitte and EY all fail to meet audit quality targets after string of high-profile failures. Independent. https://www.independent.co.uk/news/business/news/pwc-kpmg-deloitte-and-ey-auditquality- failure-frc-report-a8998321.html

Cook, E., \& Kelley. T. (1988). Auditor stress and time-budgets. The CPA Journal, 58(7), 83-86.

Coram, P., Ng, J., \& Woodliff, D. (2003). A survey of time budget pressure and reduced audit quality among Australian auditors. Australian Accounting Review, 13(29), 38-44.

Craswell, A. T., Francis, J. R. \& Taylor, S. L. (1995). Auditor brand name reputations and industry specializations. Journal of Accounting and Economics, 20(3), 297-322.

DeFond, M. L. (1992). The association between changes in client firm agency costs and auditor switching. Auditing, 11(1), 16-31.

Donnelly, D. P., Quirin, J. J., \& O’Bryan, D. (2003). Attitudes toward dysfunctional audit behavior: The effects of locus of control, organizational commitment, and position. Journal of Applied Business Research, 19(1), 95- 108.

Elshawarby, M. A. (2017). Auditor's professional specialization role in reducing the potential negative effects of mandatory audit-firm rotation on audit quality. Journal of Accounting \& Marketing, 6(3), 1-9.

Espinosa-Pike, M. \& Barrainkua, I. (2016). An exploratory study of the pressures and ethical dilemmas in the audit conflict. Revista de Contabilidad, 19(1), 10-20.

Ettredge, M. L., Bedard, J. C., \& Johnstone, K. M. (2008). Empirical tests of audit budget dynamics. Behavioral Research in Accounting, 20(2), 1-18.

Faran, Y., \& Zanbar, L. (2019). Do required fields in online surveys in the social sciences impair reliability? International Journal of Social Research Methodology, 22(6), 637-649.

Fernando, G. D., Abdel-Meguid, A. M., \& Elder, R. J. (2010). Audit quality attributes, client size and cost of equity capital. Review of Accounting and Finance, 9(4), 363-381.

Fredrick, D.M. \& Libby, R. (1986). Expertise and auditors' judgment of conjunctive events. Journal of Accounting Research, 24(2), 270-290.

Gaver, J. J., \& Utke, S. (2019). Audit Quality and Specialist Tenure. The Accounting Review, 94(3), 113-147.

Gliem, J. A., \& Gliem, R. R. (2003). Calculating, interpreting, and reporting Cronbach's alpha reliability coefficient for Likert-type scales. 2003 Midwest Research-to-Practice Conference in Adult, Continuing, and Community Education. Columbus, Ohio. Ohio State University

Government Accountability Office. (GAO) (2003). Public Accounting Firms: Required Study on the Potential Effects of Mandatory Audit Firm Rotation. GAO Report No. 04-216. November. Washington, DC: Government Printing Office.

Graham, L. E. (1985). Audit Risk--Part III. The CPA Journal (pre-1986), 55(000010), 36. 
Gramling, A. A., \& Stone, D. N. (2001). Audit firm industry expertise: A review and synthesis of the archival literature. Journal of Accounting Literature, 20, 1-29.

Granberg, L., \& Höglund, L. (2011). The auditors' way to acquire knowledge about a company's environment (Master's thesis, Kristianstad University). https://www.divaportal.org/smash/get/diva2:434617/FULLTEXT01.pdf

Green, W. (2008). Are industry specialists more efficient and effective in performing analytical procedures? A multi-stage analysis. International Journal of Auditing, 12(3), 243-260.

Gul, F. A., Fung, S. Y. K., \& Jaggi, B. (2009). Earnings quality: Some evidence on the role of auditor tenure and auditors' industry expertise. Journal of accounting and Economics, 47(3), 265-287.

Gundry, L. C., \& Liyanarachchi, G. A. (2007). Time budget pressure, auditors' personality type, and the incidence of reduced audit quality practices. Pacific Accounting Review, 19(2), 125-152.

Gunn, J. L., \& Paul, N. M. (2018). Auditor multinational expertise and audit quality. The Accounting Review, 93(4), 203-224.

Hair Jr., J.F., Black, W.C., Babin, B.J. \& Anderson, R.E. (2010), Multivariate Data Analysis: A Global Perspective. 7th Edition, Pearson Education, Upper Saddle River.

Haislip, J. Z., Peters, G. F., \& Richardson, V. J. (2016). The effect of auditor IT expertise on internal controls. International Journal of Accounting Information Systems, 20, 1-15.

Hakim, F. \& Omri, M.A. (2010). Quality of the external auditor, information asymmetry, and bidask spread: Case of the listed Tunisian firms. International Journal of Accounting \& Information Management, 18(1), 5-18.

Hammersley, J. S. (2006). Pattern identification and industry-specialist auditors. The Accounting Review, 81(2), 309-336.

Havasi, R., \& Darabi, R. (2016). The effect of auditor's industry specialization on the quality of financial reporting of the listed companies in Tehran stock exchange. Asian Social Science, 12(8), 92-103.

Herrbach, O. (2001). Audit quality, auditor behaviour and the psychological contract. The European Accounting Review, 10(4), 787-802.

Hogan, C. E., \& Jeter, D. C. (1999). Industry specialization by auditors. Auditing: A Journal of Practice \& Theory, 18(1), 1-17.

Hyatt, T. A. \& Taylor M. H. (2013). The effects of time budget pressure and intentionality on audit supervisors' response to audit staff false sign-off. International Journal of Auditing, 17(1), 38-53.

Jolly (2019, Feb 1). Decline in quality': auditors face scrutiny over string of scandals. The Guardian. https://www.theguardian.com/business/2019/feb/01/decline-in-quality-auditors-facescrutiny-over- string-of-scandals

Jones, H. (2019, July 10). UK watchdog says all top accountants fail audit quality test. Reuters. https://www.reuters.com/article/us-britain-accounts-regulator-idUSKCN1U42QR

Kaiser, H. F., \& Rice, J. (1974). Little jiffy, mark IV. Educational and Psychological Measurement, 34(1), 111-117.

Kelley, T., \& Margheim, L. (1990). The impact of time budget pressure, personality, and leadership variables on dysfunctional auditor behavior. Auditing-A Journal of Practice \& Theory, 9(2), 21- 42.

Kelley, T., \& Seiler, R. E. (1982). Auditor stress and time budgets. The CPA Journal, 52(12), 2434. 
Kemani, M. K., Grimby-Ekman, A., Lundgren, J., Sullivan, M., \& Lundberg, M. (2019). Factor structure and internal consistency of a Swedish version of the Pain Catastrophizing Scale. Acta Anaesthesiologica Scandinavica, 63(2), 259-266.

Kend, M. (2008). Client industry audit expertise: towards a better understanding. Pacific Accounting Review, 20(1), 49-62.

Knechel, W. R. (2007). The business risk audit: Origins, obstacles and opportunities. Accounting, Organizations and Society, 32(4-5), 383-408.

Kraaij, V., \& Garnefski, N. (2019). The behavioral emotion regulation questionnaire: development, psychometric properties and relationships with emotional problems and the cognitive emotion regulation questionnaire. Personality and Individual Differences, 137, 56-61.

Krishnan, J., Li, C., \& Wang, Q. (2013). Auditor industry expertise and cost of equity. Accounting Horizons, 27(4), 667-691.

Ling, Q., \& Akers, M. D. (2010). An examination of underreporting of time and premature sign off by internal auditors. Review of Business Information Systems, 14(4), 37-48.

Liu, L. L., Xie, X., Chang, Y. S., \& Forgione, D. A. (2017). New clients, audit quality, and audit partner industry expertise: Evidence from Taiwan. International Journal of Auditing, 21(3), 288-303.

Low, K. Y. (2004). The effects of industry specialization on audit risk assessments and auditplanning decisions. The accounting review, 79(1), 201-219.

Malone, C. F., \& Roberts, R. W. (1996). Factors associated with the incidence of reduced audit quality behaviors. Auditing, 15(2), 49.

Mednick, R. (1990). Independence: Let's get back to basics. Journal of Accountancy, 169(1), 8693.

Milne, M. J., \& Adler, R. W. (1999). Exploring the reliability of social and environmental disclosures content analysis. Accounting, Auditing \& Accountability Journal, 12(2), 237256.

Mohd Nor, M. N. (2011). Auditor stress: antecedents and relationships to audit quality (Doctoral dissertation, Edith Cowan University). https://ro.ecu.edu.au/theses/403

Moroney, R., \& Carey, P. (2011). Industry-versus task-based experience and auditor performance. Auditing: A Journal of Practice \& Theory, 30(2), 1-18.

Moroney, R., \& Simnett, R. (2009). Differences in industry specialist knowledge and business risk identification and evaluation. Behavioral Research in Accounting, 21(2), 73-89.

O'Keefe, T. B., Simunic, D. A., \& Stein, M. T. (1994). The production of audit services: Evidence from a major public accounting firm. Journal of Accounting Research, 32(2), 241-261.

Okoye, E. I., \& Ofoegbu, G. N. (2006). The relevance of accounting and auditing standards in corporate financial reporting in Nigeria; Emphasis on compliance. The Nigerian Accountant, 39(4), 45-53.

Olatunji, O. C., \& Adekola, D. R. (2017). The roles of Auditors in fraud detection and prevention in Nigeria deposit money banks: Evidence from South West. European Scientific Journal, 13(31), 290-306.

Otley, D. T. \& Pierce, B. J. (1996). The operation of control systems in large audit firms. Auditing: A Journal of Practice \& Theory, 15(2), 65-84.

Owhoso, V., Messier, W., \& Lynch, J. (2002). Error detection by industry-specialized teams during sequential audit review. Journal of Accounting Research, 40(3), 883-900.

Paino, H., Smith, M., \& Ismail, Z. (2010). Dysfunctional audit behavior: An exploratory study in Malaysia. Asian Review of Accounting, 18(2), 162-173. 
Pierce, B. \& Sweeney, B. (2004). Cost-quality conflict in audit firms: an empirical investigation. European Accounting Review, 13(1), 415-441.

Raghunathan, B. (1991). Premature signing-off of audit procedures: An analysis. Accounting Horizons, 5(2), 71-79.

Reichelt, K. J., \& Wang, D. (2010). National and office-specific measures of auditor industry expertise and effects on audit quality. Journal of Accounting Research, 48(3), 647-686.

Rose-Green, E., Huang, H. W., \& Lee, C. C. (2011). The association between auditor industry specialization and firms' disclosure of internal control weaknesses. International Journal of Auditing, 15(2), 204- 216.

Saha, S.S. \& Roy, M.N. (2017). Quality control procedures for statutory financial audit: An empirical study. Emerald Publishing, Bingley.

Sarens, G., \& Abdolmohammadi, M. J. (2011). Monitoring effects of the internal audit function: agency theory versus other explanatory variables. International Journal of Auditing, 15(1), $1-20$.

Shapeero, M., Chye Koh, H., \& Killough, L. N. (2003). Underreporting and premature sign-off in public accounting. Managerial Auditing Journal, 18(6/7), 478-489.

Solomon, I., Shields, M. D., \& Whittington, O. R. (1999). What do industry-specialist auditors know? Journal of Accounting Research, 37(1), 191-208.

Stephens, N. M. (2011). External auditor characteristics and internal control reporting under SOX Section 302. Managerial Auditing Journal, 26(2), 114-129.

Stewart, D. W. (1981). The application and misapplication of factor analysis in marketing research. Journal of Marketing Research, 18(1), 51-62.

Suyono, E. (2012). Determinant Factors Affecting Audit Quality: An Indonesian Perspective. Global Review of Accounting and Finance, 3(2): 42-57.

Svanström, T. (2016). Time pressure, training activities and dysfunctional auditor behaviour: Evidence from small audit firms. International Journal of Auditing, 20(1), 42-51.

Taylor, M. (2000). The effects of industry specialization on auditors' inherent risk assessments and confidence judgements. Contemporary Accounting Research, 17(4), 693- 712.

Wang, K., Sewon, O., \& Iqbal, Z. (2009). Audit pricing and auditor industry specialization in an emerging market: Evidence from China. Journal of International Accounting, Auditing and Taxation, 18(1), 60-72.

Wheaton, B., Muthen, B., Alwin, D. F., \& Summers, G. F. (1977). Assessing reliability and stability in panel models. Sociological Methodology, 8, 84-136.

Wright, S., \& Wright, A. M. (1997). The effect of industry experience on hypothesis generation and audit planning decisions. Behavioral Research in Accounting, 9, 273- 294.

Yazan Yaseen, A., Wan Sallha, Y., Muhammad Ahmar, A., \& Anas Najeeb, G. (2019). The effect of audit tenure and audit firm size on the audit quality: Evidence from Jordanian auditors. International Journal of Business and Technopreneurship, 9(1), 15-24.

Yuen, D. C., Law, P. K., Lu, C., \& Qi Guan, J. (2013). Dysfunctional auditing behaviour: Empirical evidence on auditors' behaviour in Macau. International Journal of Accounting \& Information Management, 21(3), 209-226. 
Appendix 1: Research Instrument

\section{SECTION 1}

On the following section there are six statements related with the auditor's industry knowledge. Please CIRCLE the number corresponding to your level of agreement with each statement using the following response scale.

\begin{tabular}{|c|c|c|c|c|c|}
\hline \multirow[b]{2}{*}{$\begin{array}{l}\text { Auditor's professional specialization contributes to the } \\
\text { compliance of the auditors with the requirements of } \\
\text { professional auditing rules. }\end{array}$} & \multicolumn{3}{|c|}{$\begin{array}{l}\text { Strongly } \\
\text { Disagree }\end{array}$} & \multicolumn{2}{|c|}{$\begin{array}{l}\text { Strongly } \\
\text { Agree }\end{array}$} \\
\hline & 1 & 2 & 3 & 4 & 5 \\
\hline $\begin{array}{l}\text { Auditor's professional specialization encourages } \\
\text { auditors to apply the concept of quality within the audit } \\
\text { offices, which has the greatest impact on the audit } \\
\text { quality. }\end{array}$ & 1 & 2 & 3 & 4 & 5 \\
\hline $\begin{array}{l}\text { Auditor's professional specialization contributes to } \\
\text { increasing the auditor's ability to select clients carefully. }\end{array}$ & 1 & 2 & 3 & 4 & 5 \\
\hline $\begin{array}{l}\text { Auditor's professional specialization would improve } \\
\text { audit quality make financial reporting more reliable. }\end{array}$ & 1 & 2 & 3 & 4 & 5 \\
\hline $\begin{array}{l}\text { Auditor's professional specialization contributes to } \\
\text { increase the client-specific knowledge. }\end{array}$ & 1 & 2 & 3 & 4 & 5 \\
\hline $\begin{array}{l}\text { Auditor's professional specialization contributes to } \\
\text { increase the auditor's ability to determine weak client } \\
\text { explanations. }\end{array}$ & 1 & 2 & 3 & 4 & 5 \\
\hline
\end{tabular}

\section{SECTION 2}

Please state your agreements on the following statement related with premature sign off. Please $\underline{\text { CIRCLE }}$ the number that corresponds best to your answer.

\begin{tabular}{|c|c|c|c|c|c|}
\hline & $\begin{array}{l}\text { Strongly } \\
\text { Disagree }\end{array}$ & & & & $\begin{array}{l}\text { Strongly } \\
\text { Agree }\end{array}$ \\
\hline Premature sign-off is unethical. & 1 & 2 & 3 & 4 & 5 \\
\hline $\begin{array}{l}\text { The auditor's professional judgment is always sufficient } \\
\text { to overrule the performance of a specific audit step. }\end{array}$ & 1 & 2 & 3 & 4 & 5 \\
\hline $\begin{array}{l}\text { The person performing an audit procedure should never } \\
\text { omit a planned procedure without consulting a } \\
\text { supervisor. }\end{array}$ & 1 & 2 & 3 & 4 & 5 \\
\hline $\begin{array}{l}\text { I am aware that some auditors in my audit team sign off } \\
\text { required audit steps, not covered by other audit steps, } \\
\text { without completing the work or noting the omission of } \\
\text { procedures. }\end{array}$ & 1 & 2 & 3 & 4 & 5 \\
\hline
\end{tabular}




\begin{tabular}{|c|c|c|c|c|c|}
\hline $\begin{array}{l}\text { Review procedures in my audit team are adequate to } \\
\text { detect premature sign-offs. }\end{array}$ & 1 & 2 & 3 & 4 & 5 \\
\hline $\begin{array}{l}\text { In my opinion, premature sign-offs are the result of } \\
\text { time budget constraint. }\end{array}$ & 1 & 2 & 3 & 4 & 5 \\
\hline $\begin{array}{l}\text { In my opinion, premature sign-offs are the result of } \\
\text { inadequate supervision. }\end{array}$ & 1 & 2 & 3 & 4 & 5 \\
\hline $\begin{array}{l}\text { In my opinion, premature sign-offs could be reduced by } \\
\text { tighter supervision of all auditors. }\end{array}$ & 1 & 2 & 3 & 4 & 5 \\
\hline $\begin{array}{l}\text { During the past } 12 \text { months, I signed off audit steps } \\
\text { without completing the work or noting the omission of } \\
\text { the procedure(s). }\end{array}$ & 1 & 2 & 3 & 4 & 5 \\
\hline
\end{tabular}

